\title{
Relationship Between Viral Load and Prohepcidin Levels in Chronic Hepatitis B Patients
}

\author{
Kronik Hepatit B Hastalarında Viral Yük ve Prohepsidin Düzeyi Arasındaki llișki
}

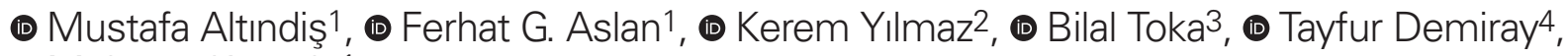 \\ (D) Mehmet Köroğlu1
}

'Sakarya University Faculty of Medicine, Department of Medical Microbiology, Sakarya, Turkey

2 Soma State Hospital, Microbiology Laboratory, Manisa, Turkey

3University of Health Sciences Turkey, Konya Training and Research Hospital, Clinic of Gastroenterology, Konya, Turkey

${ }^{4}$ Sakarya University Faculty of Medicine, Department of Clinical Microbiology, Sakarya, Turkey

Keywords: Chronic hepatitis B, HBV-DNA, prohepcidin

Anahtar Kelimeler: Kronik hepatit B, HBV-DNA, prohepsidin

Altındiş M, Aslan FG, Yılmaz K, Toka B, Demiray T, Köroğlu M. Relationship Between Viral Load and Prohepcidin Levels in Chronic Hepatitis B Patients. Viral Hepat J. 2020;26:174-175.

\section{Dear Editor;}

Viral hepatitis represents a major cause of chronic liver disease leading to cirrhosis and hepatocellular carcinoma (HCC), worldwide. Increased iron storage has an important role in the diseases associated with Hepatitis B virus (HBV). This may be associated with the iron's ability to produce oxidative stress and cause tissue damage and chronic inflammation in the liver. Hepcidin is a hormone which functions as a key regulator in iron homeostasis and is produced in the liver. Understanding the regulation of hepcidin in chronic viral hepatitis (CVD) associated diseases may explain the relation among viral hepatitis, iron accumulation and HCC to a great extent $(1,2)$. In this study, serum prohepcidin levels were assessed in four different groups of patients followed up with the diagnosis of chronic hepatitis $B(\mathrm{CHB})$. The aim of this study was to evaluate prohepcidin levels with HBV-DNA levels in HBV infected patients and healthy volunteers.

The study included the serum samples, which were sent to Sakarya University, Sakarya Training and Research Hospital, Medical Microbiology Laboratory and routinely tested and then stored at -80 ${ }^{\circ} \mathrm{C}$, from patients who were followed up with $\mathrm{CHB}$ infection and healthy population. Patients with chronic hepatic or hematologic conditions were excluded. The participants were divided into four groups according to their status of using medication and level of viral load $\left(\geq 10^{5} \mathrm{IU} / \mathrm{mL}\right.$ was accepted as high). The serum prohepcidin levels in the samples of the study were investigated with the method of ELISA test (Boster, Pleasanton CA).

A total of 60 patients with $\mathrm{CHB}$ (33 male, mean age $42.4 \pm 6.3$ years) and 20 healthy volunteers were included in the study. The prohepcidin levels of the control group were found to be higher than patient groups. Also, it was detected to be higher in those with the viral load $<10^{5} \mathrm{IU} / \mathrm{mL}$ compared to those with the viral load $\geq 10^{5} \mathrm{IU} / \mathrm{mL}$. The prohepcidin levels of the control group and patient groups are illustrated in the Table 1.

Hepcidin is a circulating peptide hormone that is synthesized mainly from the liver and is the main regulator of systemic iron balance. As it is produced mainly by hepatocytes, liver diseases may affect hepcidin production. There are a few studies evaluating hepcidin expression in CVD but remains controversial. Understanding the regulation of hepcidin in HBV-associated diseases may increase our knowledge on the relationship among

Address for Correspondence: Mustafa Altındiş MD, Sakarya University Faculty of Medicine, Department of Medical Microbiology, Sakarya, Turkey E-mail: maltindis@sakarya.edu.tr ORCID ID: orcid.org/0000-0003-0411-9669 Received: 16.03.2020 Accepted: 29.09.2020

${ }^{\circ}$ Copyright 2020 by Viral Hepatitis Society / Viral Hepatitis Journal published by Galenos Publishing House. 


\begin{tabular}{|c|c|c|c|c|c|}
\hline Prohepcidin-level (pg/mL) & $\begin{array}{l}\text { Patients on medication } \\
\text { and with HBV-DNA }<10^{5} \\
\mathrm{IU} / \mathrm{mL},(\mathrm{n}=15)\end{array}$ & $\begin{array}{l}\text { Patients on medication } \\
\text { and with HBV-DNA }>10^{5} \\
\mathrm{IU} / \mathrm{mL} \text {, } \\
(\mathrm{n}=15)\end{array}$ & $\begin{array}{l}\text { Patients who were not on } \\
\text { medication and with HBV- } \\
\text { DNA }<10^{5} \mathrm{IU} / \mathrm{mL} \text {, } \\
(\mathrm{n}=15)\end{array}$ & $\begin{array}{l}\text { Patients who were not on } \\
\text { medication and with HBV- } \\
\text { DNA }>10^{5} \mathrm{IU} / \mathrm{mL} \text {, } \\
(\mathrm{n}=15)\end{array}$ & $\begin{array}{l}\text { Control group, } \\
(n=20)\end{array}$ \\
\hline Minimum & 133 & 131 & 70 & 216 & 629 \\
\hline Maximum & 1272 & 851 & 1132 & 1117 & 1819 \\
\hline Mean value & 644.06 & 619.57 & 742.88 & 695.55 & 1185.1 \\
\hline
\end{tabular}

viral hepatitis, iron storage and HCC. Although the determination of hepcidin levels by immunoassays and mass spectrometry has begun to be used more, accurate and easy hepcidin quantitation remains as a problem.

The elevated serum iron level has been described in chronic liver diseases, including $\mathrm{CHC}$, nonalcoholic steatohepatitis and alcoholic liver disease $(3,4)$. However, some other studies show that hepcidin was down-regulated in HCV and liver cirrhosis, and ferritin levels being negatively correlated (5). There are few reports of hepcidin levels in patients with HBV infections, and the results are inconsistent. Wang et al. (2) showed that serum ferritin and hepcidin levels were significantly higher in patients with hepatitis $B$ than in controls, and positive correlations were found between log (hepcidin) and log (HBV-DNA) (2). However; Armitage et al. (4) found that there was no evidence of hepcidin up-regulation during the primary viremia phases of HCV or HBV infection.

We found that prohepcidin levels are significantly lower in patients with $\mathrm{CHB}$, in our study. Since our study had cross-sectional design, the prognostic value of low prohepcidin in chronic HBV could not be assessed. There is still need for further research on physiological and pathological changes of hepcidin during HBV infection for better understanding clinical monitorization and management of $\mathrm{HBV}$-associated diseases.

\section{Ethics}

Peer-review:

\section{Authorship Contributions}

Concept: M.A. Design: M.A., M.K., F.G.A., Data Collection or Processing: M.A., T.D., K.Y., F.G.A., Analysis or Interpretation:
M.A., T.D., B.T., FG.A., Literature Search: M.A., M.K., B.T. Writing: M.A., B.T.

Conflict of Interest: No conflict of interest was declared by the authors.

Financial Disclosure: The authors declared that this study has received no financial support.

\section{References}

1. Olmez OF, Gurel S, Yilmaz Y. Plasma prohepcidin levels in patients with chronic viral hepatitis: relationship with liver fibrosis. Eur $J$ Gastroenterol Hepatol. 2010;22:461-565.

2. Wang J, Dong A, Liu G, Anderson GJ, Hu TY, Shi J, Hu Y, Nie G. Correlation of serum hepcidin levels with disease progression in hepatitis B virus-related disease assessed by nanopore film based assay. Sci Rep. 2016;6:34252.

3. Di Bisceglie AM, Axiotis CA, Hoofnagle JH, Bacon BR Measurements of iron status in patients with chronic hepatitis. Gastroenterology 1992;102:2108-2113.

4. Armitage $A E$, Stacey $A R$, Giannoulatou $E$, Marshall E, Sturges P, Chatha K, Smith NM, Huang X, Xu X, Pasricha SR, Li N, Wu H, Webster C, Prentice AM, Pellegrino P, Williams I, Norris PJ, Drakesmith $\mathrm{H}$, Borrow P. Distinct patterns of hepcidin and iron regulation during HIV-1, HBV, and HCV infections. Proc Natl Acad Sci U S A. 2014;111:12187-12192.

5. Fujita N, Sugimoto $R$, Takeo M, Urawa N, Mifuji R, Tanaka $H$, Kobayashi Y, Iwasa M, Watanabe S, Adachi Y, Kaito M. Hepcidin expression in the liver: relatively low level in patients with chronic hepatitis C. Mol Med. 2007;13:97-104. 